Georgia State University

ScholarWorks @ Georgia State University

2-3-2012

\title{
COMPETING RISKS ANALYSIS OF DROPOUT AND EDUCATIONAL ATTAINMENT FOR STUDENTS WITH DISABILITIES
}

Li Feng

Texas State University-San Marcos, LF20@txstate.edu

Tim R. Sass

Georgia State University, tsass@gsu.edu

Follow this and additional works at: https://scholarworks.gsu.edu/uwrg_workingpapers

\section{Recommended Citation}

Feng, Li and Sass, Tim R., "COMPETING RISKS ANALYSIS OF DROPOUT AND EDUCATIONAL ATTAINMENT FOR STUDENTS WITH DISABILITIES" (2012). UWRG Working Papers. 48.

https://scholarworks.gsu.edu/uwrg_workingpapers/48

This Article is brought to you for free and open access by the Usery Workplace Research Group at ScholarWorks @ Georgia State University. It has been accepted for inclusion in UWRG Working Papers by an authorized administrator of ScholarWorks @ Georgia State University. For more information, please contact scholarworks@gsu.edu. 
Working Paper 2012-2-3

February 2012

\section{Competing Risks Analysis of Dropout and Educational Attainment for Students with Disabilities}

Li Feng

Texas Sate University - San Marcos

Tim R. Sass

Georgia State University 


\title{
COMPETING RISKS ANALYSIS OF DROPOUT AND EDUCATIONAL ATTAINMENT FOR STUDENTS WITH DISABILITIES
}

\author{
by \\ Li Feng \\ Department of Finance and Economics \\ McCoy College of Business Administration \\ Texas State University-San Marcos \\ San Marcos, TX 78666 \\ Email: LF20@txstate.edu \\ Tim R. Sass \\ Department of Economics \\ Andrew Young School of Policy Studies \\ Georgia State University \\ Atlanta, GA 30303 \\ Email: tsass@gsu.edu
}

February 2012

\begin{abstract}
We employ individual-level panel data on students with disabilities in Florida to determine the relationship between high school teacher quality and the likelihood a student drops out and the type of diploma they receive if they do finish high school. Our data include five cohorts of $9^{\text {th }}$ graders from 1998/99-2002/03 and link students to individual teachers for each class the students are enrolled in at every grade level. We use both competing risks proportional hazard Cox model and propensity score matching to estimate the effect of teachers. We find some evidence of significant negative correlations between teacher experience and the likelihood of dropping out of high school and between drop out probabilities and teachers with advanced degrees. Competing risks analysis show that special education certification for teachers of special education classrooms leads to both higher hazard of obtaining special education diploma and lower hazard of obtaining standard high school diploma. The average treatment effects on the treated (ATT) show that study-defined high quality teacher exposure during high school career leads to lower dropout rate and higher probability of graduating with diplomas.
\end{abstract}

\footnotetext{
* This research is supported by grant R324B070018 from the U.S. Department of Education. We wish to thank the staff of the Florida Department of Education's K-20 Education Data Warehouse for their assistance in obtaining and interpreting the data used in this study. We have received helpful comments from Paul Sindelar, Bonnie Billingsley, and conference participants of Teacher Education Division of Council for Exceptional Children. Yoo Sun Reiss, Ryan Murphy and John Gibson provided excellent research assistance. The views expressed is this paper are solely our own, however, and do not necessarily reflect the opinions of the Florida Department of Education or the U.S. Department of Education.
} 


\section{Introduction}

The high dropout rate of high-school students, particularly those in so-called "drop out factories" in which 60 percent or fewer of entering freshmen make it to the $12^{\text {th }}$ grade, has raised alarm among educators and policy makers. However, the numbers for the general high-school age population pale in comparison to the extent of drop out among youth with disabilities. In 2003-04 31.1 percent of students with disabilities ages 14 to 21 had dropped out of school (U.S. Department of Education (2009)), while the dropout rate for all youth was two-thirds lower, at 9.9 percent (Cataldi, Laird and KewalRamani (2009)). ${ }^{1}$ The high dropout rate is associated with subsequent educational and employment outcomes as well. Among students with disabilities, 50.8 percent who complete high school enroll in some sort of post-secondary institution within four years of leaving high school while only a third as many non-completers (16.6 percent) do so (Newman, et al. (2009)). Similarly, 61.0 percent of students with disabilities who completed high school were employed whereas only 40.7 percent of drop outs reported being currently employed (Newman, et al. (2009)).

Although the high school dropout rate and subsequent poor post-secondary educational and employment outcomes for youth with disabilities have not gone unnoticed, existing research focuses on the efficacy of vocational and other high school transition programs targeting students with disabilities. In contrast, virtually nothing is known about the affects of more general educational inputs on educational attainment of students with disabilities. Using the competing risks proportional hazard Cox model supplemented with propensity score matching method, we

\footnotetext{
${ }^{1}$ There are no consistent definitions or methods of calculating dropout rates among students with and without disabilities. See a recent review of this issue by Kemp (2006).
} 
investigate whether enhancements to the training of teachers who instruct special-education students can reduce drop out and improve educational attainment for students with disabilities.

\section{Previous Literature}

\section{A. Teacher Quality and Educational Attainment of Regular Education Students}

Numerous recent studies have analyzed the relationship between teacher quality and student achievement and conclude that teacher quality is the most important school-related factor in determining student achievement (e.g. Rockoff (2004), Hanushek, et al. (2005), Rivkin, Hanushek and Kain (2005), Kane, Rockoff and Staiger (2006), Aaronson, Barrow and Sander (2007)). In comparison, there are few studies that consider the impact of teacher quality on the likelihood a student drops out of school. Using data from the National Educational Longitudinal Survey of 1988, Rumberger (1995) estimates a logit model of drop out and finds that teacher quality (as reported by students) is negatively correlated with the likelihood of dropping out in $8^{\text {th }}$ grade. More recently, Koedel (2008) uses micro-level panel data from four San Diego high schools to investigate the impact of individual mathematics teachers on the likelihood a student will not complete high school. Employing an innovative instrumental variables strategy, he finds that the identity of one's teachers does influence the probability of dropping out. However, the magnitude of teachers' effects on high school completion is unrelated to their effects on student achievement or teacher "value added." Koedel also analyzes the effect of teacher credentials on student drop out probabilities. He finds that in two of the four schools studied, being exposed to an above-average number of math teachers with advanced degrees decreases the likelihood of drop out, but not in the other two high schools. Exposure to teachers with undergraduate degrees 
in math, to fully-certified math teachers or to experienced math teachers are not significantly related to the probability of drop out.

\section{B. Dropout Decision and Educational Attainment of Special Education Students}

Several studies in the special education literature have investigated the effects of high school programs on dropout and graduation outcomes for students with disabilities. Many of the studies, however, involve small samples of students or focus on a specific programmatic intervention. Few consider the possible endogeneity of program participation or course selection by students.

Two studies, Benz, Lindstrom and Yovanoff (2000) and Sinclair, Christenson, and Thurlow (2005) consider school-related factors associated with dropping out or receiving a high school diploma. The later study is notable because it employs an experimental design while the former utilizes logistic regression with limited controls for observable student characteristics. The samples in both studies are relatively small, 164 students with emotional or behavioral disabilities in Sinclair, Christenson and Thurlow and 709 students with a variety of disabilities in Benz, Lindstrom and Yovanoff. Benz, Lindstrom and Yovanoff find that the length of participation in a program that provides transition services (including instruction in academic, vocational, and independent living areas) and meeting multiple transition goals are positively correlated with receipt of a regular high school diploma. Similarly, Sinclair, Christenson and Thurlow find that participants in a program that monitored student progress and provided individualized academic interventions were less likely to drop out from high school than the control group of non-participants. 


\section{Special Education Teacher Training and Classroom Practice}

While there have been no studies that estimate the effects of teacher quality on educational attainment of students with disabilities, there is some recent evidence on the relationship between the training of special education teachers and their classroom practice. Using classroom observations and principal ratings, Sindelar, Daunic and Rennells (2004) find that graduates of a traditional special education teacher program had superior classroom practices compared to their counterparts from a university-district partnership and from a district "add-on" program. Nougaret, Scruggs and Mastropieri (2005) find similar results indicating that traditionally licensed teachers are better than emergency licensed teachers on several dimensions such as planning and preparation, classroom environment, and instruction.

\section{Econometric Models and Estimation Strategies}

\section{A. Competing Risks Proportional Hazard Cox Model}

A student's choice of whether to complete high school or to drop out can be modeled in two ways. One method is to consider the single binary outcome of whether or not a student completes high school over some fixed period of time. This is the approach taken by Koedel (2008) in his analysis of teacher quality and high school completion, as well by various studies that compare high school graduation probabilities between public and private schools (Evans and Schwab (1995), Sander and Krautman (1995), Neal (1997), Altonji, Elder, and Taber (2005)). An alternative to the cross-sectional comparison of whether a student successfully completes high school within a given time period is to conduct a survival analysis that considers both the incidence of dropping out and when (i.e. at what grade level) the non-graduation departure from school occurs. 
There are a couple of advantages to modeling the dropout/graduation choice in a survival analysis framework, rather than as a single discrete choice. First, the binary approach does not distinguish when dropout occurs; 10th-grade dropouts are treated the same as 12th-grade dropouts. Second, survival analysis allows varying impacts of teachers at different grade levels. For example, a well-trained special education teacher might be more effective at keeping students with disabilities in school when the students are freshman than later in their high school careers. Due in part to data constraints, only two prior studies, Mensch and Kandel (1988) and Upchurch and McCarthy (1990), and have used survival analysis to examine high school dropout decisions.

High school completion can take many forms, particularly for special education students. The most common way in which students complete high school is attainment of a regular high school diploma. For some students with disabilities, IEP team may waive the FCAT requirement for graduation. These students will obtain the standard diploma via FCAT waiver route, alternative test, or college or career preparation routes. We define these standard high school diplomas as "alternative standard diploma". In Florida and most other states, additional graduation options exist for students with disabilities. Special education students who cannot meet the requirements for a regular diploma may obtain a special education diploma by completing a minimum level of course credits and achieving mastery in various areas such as functional academics, independent functioning, social/emotional behavior and communication. The special education diploma is designed to prepare students for adult living and employment after graduation. It does not qualify students for entrance to institutions of higher education. There are two options under the special diploma with option 1 geared towards completing minimum course requirements. Special diploma option 2 is a venue for those who are employed 
at or above minimum wage for at least one academic semester. Next down the list, students may obtain a General Equivalency Diploma or GED. In addition to regular diplomas, GEDs and special education diplomas, students may receive a "certificate of completion," indicating that they completed high school but did not meet the standards for a degree or simply no longer attend high school because the reach the maximum age of $22 .^{2}$

We separate the possible outcomes for students with disabilities into seven broad categories - dropping out, getting GED, getting certificate of completion, obtaining special diploma option 2, special diploma option 1, alternative diploma, and standard diploma. In particular, we model the probability of special education students graduating conditional on not having dropped out between 9th and 12th grade. Such question lends well to the semi-parametric Cox proportional hazard model where the dependent variable is time until the occurrence of event or the rate of failure per time unit in the interval $[\mathrm{t}, \mathrm{t}+\Delta \mathrm{t}]$, conditional on survival at time $\mathrm{t}$. The semi-parametric Cox model does not force the baseline hazard to take on any particular distribution unlike the parametric survival models. The non-negative random number time $t$ here refers to the time period since first entry into 9th grade. Since some special education student may repeat a grade, time $t$ will not necessarily corresponds with the actual enrollment grade. Our sample consists of cohorts entering grade nine at different point in time. The length of time that a student appears in the dataset will vary accordingly depending on the entry year. Our dataset is an unbalanced panel dataset with each student having multiple observations up to the period where the event of interest occurred.

\footnotetext{
${ }^{2}$ Details of the various high school completion options can be found in Florida Department of Education (2005).
} 
Other than the omitted category of attending high school, there are seven events of interest. However, we are interested in the following five events occurring namely dropping out, obtaining special diploma option 2 or option 1, alternative diploma, and high school standard diploma. Other small likelihood events such as getting GED and certificate of completion are included as competing risks. Specifically, when we estimate the probability of graduating with standard high school diploma, we need to take account of the competing events such as dropping out and other small likelihood events such as getting GED and certificate of completion. Modeling events of obtaining high school diploma or special education diploma in the single risk Cox model assumes the independence of competing risks. However, the hazard of obtaining any type of diploma is dependent on the student not having dropped out before their 12th grade. The competing risk Cox model does not make such assumption and therefore better fitted to answer our research question of whether and when do students drop out.

Following Fine and Gray (1999), the basic Cox competing risk model specification is as follows where $h_{i j}(t)$ refers to the hazard of event $j$ occurring at time $t$ for student $i$ who is taught by teacher $\mathrm{k} .^{3}$

$$
h_{i j}(t)=\exp \left(\beta_{1 j} * X_{i}+\beta_{2 j} * S_{i}+\beta_{3 j} * Q_{i k t}\right) h_{0 j}(t)
$$

Here $h_{0 j}(t)$ is the baseline hazard of event $j$ and $\exp \left(\beta_{1 j}\right), \exp \left(\beta_{1 j}\right), \exp \left(\beta_{1 j}\right)$ are the exponential of the regression coefficients or the sub-distribution hazard ratios. There are seven possible competing events $(\mathrm{j}=1,2,3,4,5,6,7)$ for dropping out, getting GED, getting certificate of completion, obtaining special diploma option 2, obtaining special diploma option1, obtaining

\footnotetext{
${ }^{3}$ The competing risk models are estimated using Stata routine-stcrreg that were first proposed by Fine and Gray(1999).
} 
alternative diploma, obtaining standard high school diploma respectively. The overall hazard function is a summation of all seven sub-hazards. Theoretically, we could estimate all seven competing events. Practically, two small likelihood events such as getting either GED or certificate of completion were not separately estimated. They were, however, included as competing events when estimating other events of interest, say, obtaining a standard high school diploma. The sub-hazard functions are the type-specific hazard function for dropping out, obtaining special diploma option 2 or option 1, alternative diploma, and high school standard diploma.

There are three sets of independent variables. $X_{i}$ includes time-invariant student characteristics such as race, sex, Limited English Proficiency status, eligibility for free or reduced lunch, cohort dummies, and types of disabilities. $S_{\mathrm{i}}$ is a vector of course-taking patterns for special education students in grade nine. Specifically, we include one dummy variable to indicate whether the student took the standardized math test in grade eight and the score therein, one indicator variable to indicate whether the student were taught in separate settings in grade 9 , and minutes spent in four types of classrooms - special education math/ English language arts and general education math/English language arts in grade $9 . Q_{\mathrm{ikt}}$ includes the set of variables of interest - time-varying teacher qualification indicators. For both special education and general education classrooms, we include teacher's experience dummy variables for zero to two years of experience and for 3 years to 9 years of experience. We also include binary variables for whether a teacher has advanced degrees, certification in special education, and certification in high school math.

The regression coefficients are estimated separately and may differ for each type of event such as dropping out $(j=1)$, special diploma option $1(j=5)$, or standard high school diploma $(j=7)$. 
The coefficients of interest are $\beta_{3 j}$ namely the effect of the teacher qualifications on the subhazard function of event $\mathrm{j}$. We will be able to test whether teacher's particular qualifications such as special education certification is correlated with the decision to drop out or graduating. The subhazard ratio will be interpreted in the same fashion as the odds ratio. If the subhazard ratio (say $\beta_{3 j}=0.30$ ) is less than one, the effect of having teachers with certain qualifications will lead to reduction in subhazard for event $\mathrm{j}$ (say $\mathrm{j}=1$, dropping out) by $70 \%$ (1-subhazard ratio=10.30). On the other hand, if the same subhazard ratio ( say $\left.\beta_{3 j}=1.82\right)$ is greater than one, the effect of having teachers with certain qualifications suggest an increase in subhazard for event $\mathrm{j}$ (say $\mathrm{j}=8$, obtaining the standard high school diploma) by $82 \%$.

Instead of focusing on each dimension of teacher quality, we come up with two summative measures of high quality teacher. These indicators span the whole high school career for students. We measure whether a student has had any high quality teachers in their high school career. A high quality special education teacher in special education classroom is defined as someone with advanced degree, special education certification, and more than five years of experience. A high quality general education teachers in general education classroom is defined as someone with advanced degree, high school math certification, and more than five years of experience. Since the placement setting may change from one year to the next for a particular student, we also created a binary indicator to indicate the exposure to either type of high quality teachers.

\section{B. Addressing Selection Issues-Propensity Score Matching}

In any non-experimental investigation of the effects of teacher quality, there is potential for selection bias due to non-random assignment of students to schools, student sorting across different courses, and non-random allocation of teachers to classrooms within a subject. These 
problems are magnified in the special education context where students with more severe impairments are typically tracked into separate special education courses and less significantly impaired students are more likely to be mainstreamed with the general student population. Further some teachers of regular education may have a disproportionate number of students with disabilities in their classes either because they are more willing or more able to instruct students with disabilities who are mainstreamed.

We employ propensity score matching to attempt to address the non-random sorting of students into classrooms and teachers into classrooms (Rosenbaum and Rubin(1983), Dehejia and Wahba(1999)). ${ }^{4}$ We include a variety of observable student characteristics, including eighth grade test scores, disability category, student demographics and students' allocation of time (minutes spent in each type of classrooms) between regular education and special education courses when they first enter high $\operatorname{school}\left(\mathrm{X}_{\mathrm{i}}\right.$ and $\mathrm{S}_{\mathrm{i}}$ terms in equation (1)). Conditional on these time-invariant student characteristics, we estimate a logit model of the probability of being "treated" or ever being taught by a high quality general education teacher or a high quality special education teacher. Students were then matched based on the estimated propensity score or the probability of exposure to high quality teacher. Thus, we have a control groups based on students' pre-treatment characteristics. The difference in outcomes such as dropping out will be the differences between the mean outcomes for "treated" group or students who were exposed to high quality special education teacher and the mean outcome for "control" group or students who were similar to the treatment group in all of the observable dimensions. Propensity score matching provides an estimate of the average treatment effect for the treated (ATT). We also

\footnotetext{
${ }^{4}$ The propensity score matching estimator are obtained using Stata routine - psmatch2.
} 
provide the corresponding ordinary least square (OLS) estimation that includes the dummy variable of ever being taught by a high quality teacher. The coefficient for the binary variable of being taught by high quality teacher will provide the sample average treatment effect (SATE). Since OLS estimation assumes the exogeneity of treatment, we prefer the ATT on two grounds. First of all, OLS estimation leads to inconsistent and biased estimation of the effect of being treated when exogeneity assumption is violated (Guo and Fraser(2010)). Secondly and more importantly, we are interested in the treatment effect on those actually received treatment.

\section{Data and Sample Selection}

The data requirements for analysis of the effects of teacher quality on educational attainment are substantial. Student records must be linked over time and contain information on high school enrollment. Further, student records must be linked to information about the teachers who instruct them. The difficulty in matching student and teacher records is exacerbated in special education, since students with disabilities often have multiple teachers within a given subject.

To meet the challenges of linking teachers to students and students to high school and post-secondary outcomes, we employ a unique statewide database from Florida. The Florida Education Data Warehouse (FLEDW) contains individual-level longitudinal data for the universe of public school students and teachers in the state from 1995 forward, including about 400,000 special education students each year. Furthermore, the Florida data contain the entire enrollment

record for each student, including the minutes per week spent in each classroom. Thus we can determine each and every teacher a student is exposed to and time spent with each. The FLEDW includes withdrawal information for students when they leave public school as well records of 
diplomas and other educational awards. The combination of withdrawal and award information allows us to delineate high school drop outs and the type of diploma received by high school completers.

\section{A. Student Characteristics}

In our analyses we employ a variety of covariates to control for the ability of students when entering high school. Basic demographic variables include race/ethnicity, gender, limited English proficiency (LEP) program participation, and free/reduced-price lunch status (a proxy for family income) in $8^{\text {th }}$ grade..$^{5}$ Disability status is measured by a set of five disability category indicators: speech/language disability, mental disability, physical disability, behavioral/emotional disability and specific learning disabilities; "other disability" is the omitted category. ${ }^{6}$ Disability status is determined during the first semester of ninth grade.

To capture both ability and the effect of pre-high-school educational inputs, we also employ eighth-grade test score information for students entering ninth grade. We use scores from the math and reading "Sunshine State Standards" Florida Comprehensive Achievement Tests (FCAT-SSS). ${ }^{7}$ The FCAT-SSS is a criterion-based exam designed to test for the skills that students are expected to master at each grade level. The minimum score is 100 and the

\footnotetext{
${ }^{5}$ Because LEP information is only available from 1998/99 forward, we use a student's LEP status in ninth grade. All other variables are measured when the student is in eighth grade.

${ }^{6}$ These six categories are aggregated from 18 detailed disability classifications. Speech/Language includes both "speech impaired" and "language impaired" students. Mental disabilities include "educable mentally handicapped," "trainable mentally handicapped," "profoundly mentally handicapped," "traumatic brain injured" and "developmentally delayed." Physical disabilities include "orthopedically impaired," "deaf or hard of hearing," "visually impaired" and "dual sensory impaired." Behavioral/emotional disabilities include "emotional/behavioral disability," "autistic" and "severely emotionally disturbed." Other disabilities include "hospital/homebound," "established condition" and "other health impaired."

${ }^{7}$ In 1999/00-2007/08 the State also administered the FCAT norm-referenced test or FCAT-NRT, which was the Stanford Achievement Test. Since $8^{\text {th }}$-grade test administration of the FCAT-NRT began two years later than the FCAT-SSS, we only use FCAT-SSS scores in the analysis.
} 
maximum is 500. Given that many students with significant intellectual impairments do not take the FCAT-SSS, we utilize two variables in our analysis. The first variable is an indicator for students who were enrolled in a public school in eighth grade, but did not take the exam. The second equals the student's test score and is set to zero if the student didn't take the exam.

As an additional control, in most of the models we also include a measure of the student's schedule in the first semester of ninth grade. Specifically, we follow the categorization used on student's individualized education plans (IEPs) and employ an indicator for students who spend 40 percent or less of their instructional time in classes with non-disabled peers. Typically these are students with more severe impairments.

\section{B. Matching Students to Teachers}

Matching students with their teachers and determining which teachers are responsible for instruction is particularly challenging in the case of special education. Students with disabilities often take both regular education and special education courses in the same subject at a point in time, though this is more of an issue in primary school where mainstreaming is more common. At the high school level, students may also take multiple regular education courses in a subject. Similar to our previous work on student achievement (Feng and Sass (2009)), for each student in each year we track every course they take in a subject (math and English-Language Arts (ELA)). From this we determine the identities of the teachers teaching the subject-relevant regular education and special education courses. ${ }^{8}$ If a student has a single teacher for their regular

\footnotetext{
8 Not only are each classroom and teacher identified, but "pull-out" sessions with speech-language pathologists (SLPs) are assigned separate course identifiers and each SLP has an employee identifier so we can also determine the exposure to SLPs for students with speech/language impairments. In the present analysis, however, we simply exclude all academic courses taught by someone other than a teacher. Other related service providers, such as occupational therapists, are identified in the data but are not linked to specific courses. Thus we can not match them to specific students.
} 
education courses in a subject throughout the year, we designate that teacher as their "solely responsible" regular education teacher. Similarly, if all of their subject-relevant special education courses are taught by a single teacher, that teacher is deemed to be their "solely responsible" special education teacher in the relevant subject. When measuring the characteristics of teachers, only student-year observations where there is a solely responsible teacher are used in the analysis.

The measurement of teacher characteristics depends on the type of analysis. In our competing risks proportional hazard analysis, we measure the characteristics of the specific solely responsible regular-education and special-education teachers a student encounters each year they are in school. In the competing risks analysis, we examine both the specific characteristics (experience/certification/advanced degree) of teachers and an overall teacher quality measure as explained in methodology section. In our propensity score matching analysis, we create a time-constant measure for exposure to high quality teachers that examine the whole high school career of the student instead of the time-varying teacher characteristics used in competing risks analysis.

\section{Teacher Characteristics}

Not only is the FLEDW a rich source of student information, it also provides a wealth of information on teachers as well. For each Florida public school teacher the FLEDW provides their basic demographic characteristics (age, sex, and race/ethnicity) and years of teaching experience. The FLEW also provides data on each teacher's certification status (professional or temporary), subject area certification (eg. special education) and whether they possess an advanced degree. Through matching of files from the Department of Education's Staff Information Database we can identify each and every professional development course each 
teacher participates in during their career. Further, we can determine the subject matter of each course (eg. math pedagogy) and the number of hours of instruction. We can therefore precisely measure the amount and type of professional development each teacher receives. For the subsample of Florida public school teachers who attended a Florida public community college or university since 1995 the FLEDW contains their complete transcript information, including each course they took and the degrees they earned. We can therefore quantify the number and types of teacher preparation courses taken. Because Florida has a uniform course numbering system, we are able to create variables that describe each course according to its content. In particular we can distinguish special education courses form other teacher preparation courses. The FLEDW also contains entrance exam information for teachers who began their college career at a four-year university in Florida in 1995 or later. Lastly, information on teacher certification exam scores available from the Florida Department of Education's Bureau of Teacher Ceritification. As a crude measure of teacher ability, we measure whether or not a teacher passed the general knowledge math and reading exams on the first try.

\section{Student Outcomes}

For all students, whether they take standardized tests or not, we determine if they complete high school and the type of the diploma they receive. For those students who do not complete high school we can also determine when they drop out. Complete information on high school enrollment and diplomas is available in the FLEDW. Not only do the enrollment records indicate when a student leaves a Florida public school, the reason for withdrawal is also indicated. Thus, for example, we can determine if a student left to attend a school in another state or if she left with no intention of returning to school. There are multiple diploma options in 
Florida. For students with disabilities the top four most common are: standard high school diploma, alternative diploma, and special diploma (option1 and 2).

\section{E. Sample Coverage}

The available data cover five cohorts of students of first-time-in- $9^{\text {th }}$-grade students. Disability status of students is only available beginning in the 1998/99 school year. Further, statewide achievement testing for $8^{\text {th }}$ grade students began in the $1997 / 98$ school year, so prehigh-school test scores are available beginning with the 1998/99 cohort of $9^{\text {th }}$ graders. The last available year of student data is $2005 / 06$. Given that high school completion typically takes four years, this means the last cohort that can be tracked through high school are students who started $9^{\text {th }}$ grade in 2002/03. Determining post-high school outcomes requires at least a five-year window from the beginning of high school. Thus for the analysis of drop out and high school completion we can study five cohorts who began ninth grade in 1998/99-2002/03 and for the analysis of post-secondary outcomes we include four cohorts of students who started high school in the years 1998/99-2001/02.

\section{Results}

\section{A. Descriptive Analyses}

Descriptive statistics for the five cohorts of high school students with disabilities are provided in Table 1. Students with disabilities are dis-proportionally African-American and from low-income families. Also, at the high school level, boys are much more likely to be in special education than girls. About 30 percent of $9^{\text {th }}$ graders with disabilities did not take either

of the standard achievement exams in $8^{\text {th }}$ grade and about the same proportion spend most of their school day in special education classrooms separate from their non-disabled peers. 
Students with specific learning disabilities make up the vast majority of students receiving special education services. Not surprisingly, the group of students that is most distinct are those with intellectual disabilities. About 70 percent of students with mental impairments did not take standardized exams in $8^{\text {th }}$ grade and spend most of their day separated from their typical peers. The majority of students with intellectual disabilities are black and nearly 80 percent come from low-income households. The disparity between students with intellectual and other disabilities is highlighted in Figure 1 , which shows the $8^{\text {th }}$ grade test performance of students by disability category. While the modal outcome for students with disabilities is about one-half to three-quarters of a standard deviation below the mean for the overall population of students, the modal performance of students with intellectual impairments is nearly two standard deviations below the population mean. While significant numbers of students with disabilities score at the minimum level of standardized exams, a much larger proportion of those with mental disabilities achieve only the minimum score.

Average outcomes for students by disability category are provided in Table 2 . In total, we have 130,114 students with disabilities. At the end of the follow-up period in 2005/06, some students are still attending public schools (41.4\%). About 12 percent of students with disabilities drop out of high school while $22 \%$ of them obtain a standard high school diploma. Another $6 \%$ obtain the standard diploma via FCAT waivers or college preparation courses (alternative standard diploma) while $14.4 \%$ of them obtain special diploma option 1. Students with behavioral or emotional disability have the highest dropout rate of $16.6 \%$. The percentages of students who graduate with special diploma are highest among students with mental disability and students with physical disability at $38.3 \%$ and $22.3 \%$. The percentages of students who 
graduate with standard high school diploma are highest among students with specific learning disability and speech-language disability (27.5\% and $33.9 \%)$.

Table 3 provides descriptive information for the teachers of students with disabilities. We characterize teachers by the courses they teach, not by their certification. Thus "special education teachers" are those teachers who have taught one or more special education courses while "regular education teachers" are teachers who do not teach any special education courses. While high school math teachers are more likely to be male than are ELA teachers, in both subject areas a higher proportion of regular education teachers are male. Special education teachers have about a year less experience on average than do regular education teachers, which is consistent with the greater level of attrition among special education teachers. National Board for Professional Teaching Standards (NBPTS) certification and advanced degree attainment are comparable between special education and regular education teachers, though the SAT scores of special education teachers tend to be lower, particularly among math teachers. This disparity also shows up in the lower average first-time passage of the math general knowledge certification exam.

\section{B. Competing Risks Proportional Hazard Cox Results}

There are still much debates about the best placement for special education students in terms of whether it benefit students to be mainstreamed ( Holcutt,(1996); Singer, et al. (1986); Zigmond(2003)). Though our paper does not directly address the issue of placement, the setting where students receive instruction is of importance for our analysis. In particular, we estimate our model using three distinct instructional settings, special education classroom with one solely responsible teacher, general education classroom with one solely responsible teacher only, and a 
combination of both type of aforementioned classroom setting. Table 4 to 6 presents the results for these three different settings respectively.

Table 4 shows the impact of teacher qualifications on special education students who have had at least one special education teacher. Teacher's qualifications effects are allowed to vary depending on the outcome of interests as demonstrated in the Equation (1). Similar to earlier literature on nondisabled students, female students with disabilities are less likely to drop out of school and more likely than male students to obtain diploma except special education diploma option 2. Black and Hispanic students and students in poverty are more likely to drop out of schools. Black and Hispanic students are more likely to obtain alternative diploma than white students. Students in poverty and black students are also less likely to obtain standard high school diploma. Previous literature has documented that Black students are at higher risk to be categorized into high-incidence categories of mild mental retardation, emotional disturbance, and learning disabilities(De Valenzuela, Copeland, Qi, and Park(2006), Donovan and Cross(2002)). To the extent that minority students are over-represented in special education, our finding may have implications on their future labor market earnings.

Compared with students with other disabilities, students with learning disabilities and emotionally disturbed students are more likely to drop out while students with physical disabilities are less likely to drop out. For mentally challenged students and emotionally disturbed students are less likely to obtain either types of special education diplomas. Students who spent less than $40 \%$ of their days with non-disabled peers are less likely to be awarded with either special education diploma or standard high school diploma.

Students who were taught by at least one special education teacher during their high school were included in Table 4. In general, having a more qualified teacher in terms of years of 
experience, advanced degrees, and certifications will lead to lower drop out rate and higher rate of graduation. Specifically, having a teacher with less than three years of experience instead of a teacher with more than nine years of experience will increase the hazard of dropping out by $17.5 \%$ and reduce the hazard of obtaining a standard high school diploma by $9.1 \%$. Exposure to a special education teacher with advanced degree translate to $5.7 \%$ decrease in the hazard of dropping out and $4.3 \%$ increase in the hazard of graduating with standard high school diploma. Going from a uncertified teachers to a teacher certified in special education will lead to $77.8 \%$ increase in hazard of graduating with special diploma option 2 and $68.5 \%$ higher hazard rate of obtaining option 1 diploma. At the same time, certification in special education seems to be associated with worse outcome as measured in lower rates of alternative diploma and high school diploma and higher dropout rate. This may due to the fact that teachers certified in special education who are teaching these separate special education class may channel these students to certain diploma options such as special diploma option 1 or 2. Other possible explanation might be the selection bias. Interestingly, going from a uncertified teacher who is teaching special education classroom to a teacher who is certified in high school math will nearly triple(subhazard ratio $=2.832$ ) the hazard of graduating with a standard high school diploma.

Table 5 report the competing risk Cox model results for students who were taught in general education math classrooms with at least one solely responsible teacher. Similar to Table 4, better qualified teachers leads to better outcomes. Having a teacher with less than three years of experience leads to $24 \%$ increase in hazard rate of dropping out(17\% in Table 4$)$ and reduce the hazard of obtaining a standard high school diploma by 3.7\%(9.1\% in Table 4). If a general education teacher have an advanced degree, the hazard of graduating with a standard high school diploma goes up by $3 \%(4.3 \%$ in Table 4$)$. Similar to Table 4 , findings on the certification status 
is more nuanced. Certification in high school math leads to nearly $70 \%$ increase in the hazard of obtaining high school diploma (subhazard ratio of 1.689 compared to 2.832 in Table 4). Having a teacher who is certified only in special education will leads to $40.4 \%$ (68.5\% in Table 4) increase in the hazard of obtaining special diploma option 1. Being certified in special education also translates into greater hazard of dropping out and lower likelihood of obtaining high school diploma. To the extent that principal or school administrators may selectively place certain students into certain teachers' classrooms, we would expect to see that certified special education teachers who are teaching general education math class may get a large share of special education students with more severe disability. These teachers may have more information concerning the different options available for special education students.

Table 6 shows the kind of arrangement usually referred to in the literature as inclusive settings with supportive instruction in special education classroom. Compared to samples in Table 4 and 5 , the number of observations is smaller in Table 6 . This might be due to the resource constraint faced by smaller school districts to hire enough teachers to teach in both general education math and special education math classrooms.

Most of the results in Table 6 are consistent with other two settings in Table 4 and 5. The exception is the coefficients for the certification status. For students who are mostly spending time in general education classroom, the effect of having a general education teacher certified in special education leads to better outcomes. Specifically, going from uncertified teachers to a teacher certified in special education nearly double the hazard of obtaining the standard high school diploma(suhazard ratio=1.996). This is in stark contrast with students who were taught in general education classroom only in Table 5. General education teachers certification in special education reduces the hazard of obtaining high school diploma by $7 \%$ (subhazard ratio=0.926). 
Similar to Table 4, going from a uncertified teacher to a teacher certified in high school math in the special education classroom leads to increase in hazard of getting alternative diploma and high school diploma. To summarize, certification in special education is important for teachers who teach general education classroom and that certification in high school math is important for teachers who teach special education classroom. From these results it seems that the skill complementarity is important in ensuring students' success in educational attainment.

Table 7 presents the impact of being exposed to these high quality teachers on the subhazard of dropping out, obtaining special diploma or high school diploma. Each row of Table 7 focuses on a different measure of teacher quality and each column represents different outcomes for students. Each cell of Table 7 reports the subhazard ratio from a different specification. Overall high quality teachers lead to better outcomes for special education students. Having a high quality special education teacher leads to reduction in the hazard rate of dropping out by $4.9 \%$ and increase in the hazard rate of getting special diploma option 2 by $32.5 \%$ or option 1 by $23.3 \%$. Having a high quality teacher in general education classroom setting leads to $40 \%$ lower in the hazard rate of dropping out and $28.5 \%$ increase in the hazard rate of high school diploma. Having either type of high quality teachers leads to reduction in the hazard rate of dropping out by $23.8 \%$ and increase in the hazard of getting high school diploma by $17 \%$.

Competing risks Cox model assumes that drop out occur only once. However, anecdotal evidence and prior literature has demonstrated that students do return and finishing their high school (Tyler and Lofstrom (2009)). To investigate this phenomenon, we focus on those high school dropouts. Our data has 20,647 unique cases of dropout students. Among these, 15,666 students or $75 \%$ of the students would never return to school. Around $17 \%(3,484)$ would return 
to school to resume their study. About 560(2.68\%) students would end up obtaining special education diploma. Another 503(2.41\%) students will obtain standard high school diploma. This suggests there are potential for recovering some of these dropouts.

\section{B. Propensity Score Matching Results}

Jointly estimating the hazards of multiple outcomes is one of many nice features of the competing risks proportional hazard Cox models. However, to policymakers, the average treatment effect of having a high quality teacher is more important in making investment decision such as dropout prevention services for students and investment in the professional development of teachers. Table 8 presents the effect of high quality teacher in special education classroom or general education classroom on various outcomes. We also present the Ordinary Least Square (OLS) estimation results. The average treatment effect on the treated (ATT) is presented right below OLS results. To the extent that the first stage estimation of whether a student will be "treated" by a high quality teacher takes into account of the tracking, ATT address some of the selection bias. If there are any hidden biases that is not captured by the first stage estimation, ATT may still be plagued by selection bias.

In terms of dropping out, we notice that the sample average treatment effect (SATE) from the OLS estimation for being treated by high quality teacher in special education classroom is positive 1.73 percentage points. Such positive effect of high quality special education teacher on dropout might be due to compensatory matching between weaker students and more qualified teachers or selective placement based on students' disability categories and demographics. After matching on pre-treatment student demographics and course-taking patterns, the ATT is now negative 0.92 percentage points with treatment group dropout rate of $13.49 \%$ and control group 
dropout rate at $14.42 \%$. These points out the importance of taking account of tracking based on students' disability categories, demographics and grade 9 course-taking patterns.

Similar story can be told about the effect of high quality general education teachers. Without addressing the compensatory matching, student tracking and other selection bias, the effect of high quality teacher is estimated to be negative 6.39 percentage points with treatment dropout rate at $6.58 \%$ and control group dropout rate at $12.95 \%$. The corresponding ATT estimate of the effect of having high quality general education teacher is negative 2.88 percentage points $(6.58 \%$ treatment v.s. $9.46 \%$ control $)$.

Having either type of high quality teachers is associated with 2.31 percentage points reduction in the probability of dropping out. It is worth pointing out that amongst these three different settings, the dropout rate for the special education classroom only students is the highest at $13.49 \%$ and that of general education classroom lowest at $6.58 \%$. The hybrid setting dropout rate at $9.74 \%$. This fits well with the broad literature in terms of placing students in different settings according to the disability type (Fletcher (2009), Fletcher(2010)). Within each placement settings, there still exists some compensatory matching. Any selection bias that is not addressed by the first stage matching may still affect our results presented here.

High quality teachers in special education classroom translate into 6.76 percentage points higher probability of graduating with special education diploma option 1 . The probability of graduate with special diploma 1 for treatment group is $35.57 \%$ compared to $28.82 \%$. Without addressing the fact that some high quality teachers in special education classroom may be more familiar with all of the different options available for students, the naïve SATE from OLS estimator provide the difference between treatment and control group as 24.08 percentage points which is much higher than ATT estimates of 6.76 percentage points. 
High quality teachers in general education classroom translate into 15 percentage points higher probability of graduating with standard high school diploma (treatment $52.31 \%$ v.s. control $37.31 \%$ ). It is important to note that the high quality teacher in general education is defined as being certified in high school math. The ATT estimate of high quality teacher in general education classroom echo the earlier conclusion in Table 7.

Having either high quality teacher in general education classroom or special education classroom translate into 2.31 percentage points lower probability of dropping out, 2.11 percentage points higher probability of graduating with special education diploma option 1,9.12 percentage points higher probability of graduating with diploma.

\section{Summary and Conclusions}

Our preliminary analysis is the first to consider the relationship between the quality of high school teachers and educational attainment for students with disabilities. While an initial foray into a new area of research holds forth the promise of gaining insight into unexplored issues, it also comes with the challenge of tackling data and methodological issues that have not been dealt with extensively by others.

Using competing risks proportional hazard Cox model and propensity score matching, our paper provides some tantalizing suggestive evidence that the training of high school teachers have important effects on the outcomes of students with disabilities. In particular, we find fairly consistent evidence that drop out probabilities tend to decrease the greater the exposure of students with disabilities to veteran teachers with advanced degrees. When examined individually, special education certification seems to lead to higher dropout rate due to the compensatory matching of weaker students to teachers with stronger qualifications. At the same 
time, special education certification for teachers of special education classrooms also leads to higher probability of obtaining special education diploma. High school math certification for general education teacher leads to higher probability of obtaining standard high school diploma.

When examined as a bundle of teacher characteristics, we find that exposure to high quality teachers in special education classroom and/or general education classrooms leads to lower dropout rate for students with disabilities. Having high quality teachers in special education classrooms leads to greater likelihood of getting special diploma while exposure to high quality teachers in general education classrooms leads to greater likelihood of obtaining standard high school diploma.

Addressing the selection bias prevalent in any observational study like ours, we adopt propensity score matching method to obtain the Average Treatment Effect on the Treated (ATT) of being treated by our self-defined high quality teacher measure. The estimation from this section shows that high quality teacher makes a difference in terms of keeping students from dropping out and graduating with diploma. From our analysis, teachers' pre-service professional development plays an important role regardless of placement settings for students with disabilities. We suggest that any policy efforts aimed at improving outcomes for student with disabilities need to include the most important input in these students' education processteachers. 


\section{References}

Aaronson, Daniel, Lisa Barrow, and William Sander. 2007. "Teachers and Student Achievement in the Chicago Public High Schools," Journal of Labor Economics 25: 95-135.

Altonji, Joeseph G., Todd E. Elder and Christopher R. Taber. 2005. "Selection on Observed and Unobserved Variables: Assessing the Effectiveness of Catholic Schools," Journal of Political Economy 113: 151-184.

Baer, Robert M., Robert W. Flexer, Suzanne Beck, Nangy Amstutz, Lynn Hoffman, Judy Brothers, Donna Stelzer and Christine Zechman. 2003. "A Collaborative Followup Study on Transition Service Utilization and Post-school Outcomes," Career Development for Exceptional Individuals, 26:7-25.

Benz, Michael, R. Lauren Lindstrom and Paul Yovanoff. 2000. "Improving Graduation and Employment Outcomes of Students with Disabilities: Predictive Factors and Student Perspectives," Exceptional Children 66:509-529.

Cataldi, Emily F., Jennifer Laird and Angelina KewalRamani. 2009. "High School Dropout and Completion Rates in the United States: 2007" (NCES 2009-064). National Center for Education Statistics, Institute of Education Sciences, U.S. Department of Education. Washington, DC.

Clotfelter, Charles T., Helen F. Ladd and Jacob L. Vigdor. 2007. "Teacher Credentials and Student Achievement in High School: A Cross-Subject Analysis with Student Fixed Effects." CALDER Working Paper \#11.

Cox, D. R. 1972. "Regression Models and Life Tables," Journal of the Royal Statistical Society. Series B. (Methodological), 34(2): 187-220.

Dolton, P. J. \& van der Klaauw, H. W. 1995. "Leaving Teaching in the UK: A Duration Analysis," Economic Journal 105: 431-444.

Dolton, P. J. \& van der Klaauw, H. W. 1999. "The Turnover of Teachers: A Competing Risks Explanation," Review of Economics and Statistics 81(3): 543-552.

Evans, William N. and Robert M. Schwab. 1995. "Finishing High School and Starting College: Do Catholic Schools Make a Difference?" Quarterly Journal of Economics, 110: 941974.

Feng, Li and Tim R. Sass. 2009. "Special Education Teacher Quality and Student Achievement," unpublished manuscript, Florida State University. 
Florida Department of Education, Bureau of Exceptional Education and Student Services. 2005 "Diploma Decisions for Students with Disabilities: What Parents Need to Know." Tallahassee, FL.

Hanushek, Eric A., John F. Kain, Daniel M. O’Brien, and Steven G. Rivkin. 2005. "The Market for Teacher Quality.” NBER Working Paper \#11154.

Harris, Douglas N. and Tim R. Sass. 2009. "Teacher Training, Teacher Quality and Student Achievement," unpublished manuscript, Florida State University.

Harvey, Michael W., "Comparison of Postsecondary Transitional Outcomes Between Students With and Without Disabilities by Secondary Vocational Education Participation: Findings from the National Educational Longitudinal Survey,"

Heal, Laird W. and Frank R. Rusch. 1995. "Predicting Employment for Students Who Leave Special Education High School Programs," Exceptional Children, 61(5):472-487.

Hilmer, Michael. 2001. "A Comparison of Alternative Specifications of the College Attendance Equation with an Extension to Two-Stage Selectivity-Correction Models," Economics of Education Review 20: 263-278.

Jacob, Brian A. and Lars Lefgren. 2004. "The Impact of Teacher Training on Student Achievement: Quasi-Experimental Evidence from School Reform Efforts in Chicago," Journal of Human Resources 39(1):50-79.

Jenkins, S. P. 2004. “Survival Analysis,” Longitudinal Analysis Workshop (6 July). Wellington: University of Victoria.

Kane, Thomas J., Jonah E. Rockoff, \& Douglas O Staiger. 2006. "What Does Certification Tell Us About Teacher Effectiveness? Evidence from New York City," NBER Working Papers 12155, National Bureau of Economic Research.

Kemp, Suzanne. 2006. "Dropout Policies and Trends for Students with and without Disabilities," Adolescence 41(162): 235-50.

Koedel, Cory. 2008. "Teacher Quality and Dropout Outcomes in a Large, Urban School District," Journal of Urban Economics, 64:560-572.

Mensch, Barbara and Denise Kandel. 1988. "Dropping Out of High School and Drug Involvement," Sociology of Education 61(2): 95-113.

Neal, Derek. 1997. "The Effects of Catholic Secondary Schooling on Educational Achievement," Journal of Labor Economics, 15: 98-123.

Newman, Lynn, Mary Wagner, Renee Cameto and Anne-Marie Knokey. 2009. "The Post-High School Outcomes of Youth With Disabilities up to 4 Years After High School. A Report From the National Longitudinal Transition Study-2 (NLTS2)" (NCSER 2009-3017). Menlo Park, CA: SRI International. 
Nougaret, Andre, Thomas Scruggs and Margo Mastropieri. 2005. "Does Teacher Education Produce Better Special Education Teachers?," Exceptional Children 71(3): 217-229.

Rivkin, Steven G., Eric A. Hanushek and John F. Kain. 2005. "Teachers, Schools and Academic Achievement," Econometrica 73(2): 417-58.

Rockoff, Jonah E. 2004. "The Impact of Individual Teachers on Student Achievement: Evidence from Panel Data," American Economic Review, 94(2): 247-52.

Rumberger, Russell W. 1995. "Dropping out of Middle School: A Multilevel Analysis of Students and Schools," American Educational Research Journal 32(3): 583-625.

Sander, William, and Anthony C. Krautman. 1995. "Catholic Schools, Dropout Rates and Educational Attainment," Economic Inquiry, 33: 217-233.

Shandra, Carrie L, and Dennis P. Hogan. 2008. "School-to-Work Program Participation and the Post-High-School Employment of Young Adults with Disabilities," Journal of Vocational Rehabilitation, 29:117-130.

Sinclair, Mary, Sandra Christenson and Martha Thurlow. 2005. "Promoting School Completion of Urban Secondary Youth with Emotional or Behavioral Disabilities," Exceptional Children 71(4): 465-482.

Sindelar, Paul, Ann Daunic and Mary Sue Rennells. 2004. "Comparisons of Traditionally and Alternatively Trained Teachers.” Exceptional Children 12 (4): 209-223.

Stinebrickner, T. R. 1998. "An Empirical Investigation of Teacher Attrition," Economics of Education Review 17(2): 127-136.

Upchurch, Dawn and James McCarthy. 1990. "The Timing of a First Birth and High School Completion," American Sociological Review 55(2): 224-234.

U.S. Department of Education, Office of Special Education and Rehabilitative Services. 2009. " $28^{\text {th }}$ Annual Report to Congress on the Implementation of the Individuals with Disabilities Act, 2006, Vol. 1.” Washington, D.C.

Thurlow, M., Vang, M., \& Cormier, D. (2010). Earning a High School Diploma through Alternative Routes (Synthesis Report 76). Minneapolis, MN: University of Minnesota, National Center on Educational Outcomes. 
Table 1

Mean Characteristics of Florida Public School Students with Disabilities who Entered Grade 9 in 1998/1999-2002/2003 by Disability Category

\begin{tabular}{|c|c|c|c|c|c|c|c|}
\hline & All & $\begin{array}{c}\text { Specific } \\
\text { Learning } \\
\text { Disability }\end{array}$ & $\begin{array}{l}\text { Speech- } \\
\text { Language } \\
\text { Disability }\end{array}$ & $\begin{array}{c}\text { Mental } \\
\text { Disability }\end{array}$ & $\begin{array}{l}\text { Physical } \\
\text { Disability }\end{array}$ & $\begin{array}{c}\text { Behavioral/ } \\
\text { Emotional } \\
\text { Disability }\end{array}$ & $\begin{array}{c}\text { Other } \\
\text { Disability }\end{array}$ \\
\hline Female & 0.312 & 0.302 & 0.395 & 0.424 & 0.448 & 0.199 & 0.387 \\
\hline Black & 0.308 & 0.245 & 0.408 & 0.528 & 0.221 & 0.376 & 0.179 \\
\hline Hispanic & 0.156 & 0.175 & 0.153 & 0.131 & 0.182 & 0.105 & 0.117 \\
\hline Asian & 0.006 & 0.006 & 0.017 & 0.006 & 0.013 & 0.004 & 0.009 \\
\hline Limited English Proficiency & 0.019 & 0.018 & 0.033 & 0.032 & 0.029 & 0.008 & 0.016 \\
\hline Free/Reduced-Price Lunch & 0.603 & 0.555 & 0.599 & 0.775 & 0.548 & 0.677 & 0.433 \\
\hline Didn't Take Either $8^{\text {th }}$ Grade Exam & 0.286 & 0.175 & 0.139 & 0.708 & 0.344 & 0.389 & 0.289 \\
\hline Didn't Take $8^{\text {th }}$ Grade Math Exam & 0.296 & 0.190 & 0.151 & 0.700 & 0.348 & 0.396 & 0.300 \\
\hline Didn't Take $8^{\text {th }}$ Grade Reading Exam & 0.297 & 0.192 & 0.155 & 0.701 & 0.351 & 0.398 & 0.298 \\
\hline $8^{\text {th }}$ Grade Math Exam Score & 240.6 & 246.4 & 256.7 & 158.2 & 243.7 & 234.2 & 261.9 \\
\hline $8^{\text {th }}$ Grade Reading Exam Score & 232.5 & 235.4 & 244.2 & 170.3 & 240.0 & 233.0 & 259.3 \\
\hline$<40 \%$ of Time w/Non-Disabled - G. 9 & 0.331 & 0.216 & 0.101 & 0.723 & 0.467 & 0.470 & 0.448 \\
\hline Frac. of Math Time in Sp. Ed. - G. 9 & 0.309 & 0.204 & 0.088 & 0.881 & 0.372 & 0.313 & 0.222 \\
\hline Frac. of ELA Time in Sp. Ed. - G. 9 & 0.320 & 0.219 & 0.093 & 0.874 & 0.382 & 0.321 & 0.224 \\
\hline No. of Students & 132,225 & 80,888 & 6,168 & 17,712 & 3,439 & 20,792 & 3,226 \\
\hline
\end{tabular}




\section{Figure 1}

Eighth Grade Normed Test Scores for Florida Public School Students with Disabilities who Entered Grade 9 in 1998/1999-2002/2003 by Disability Category

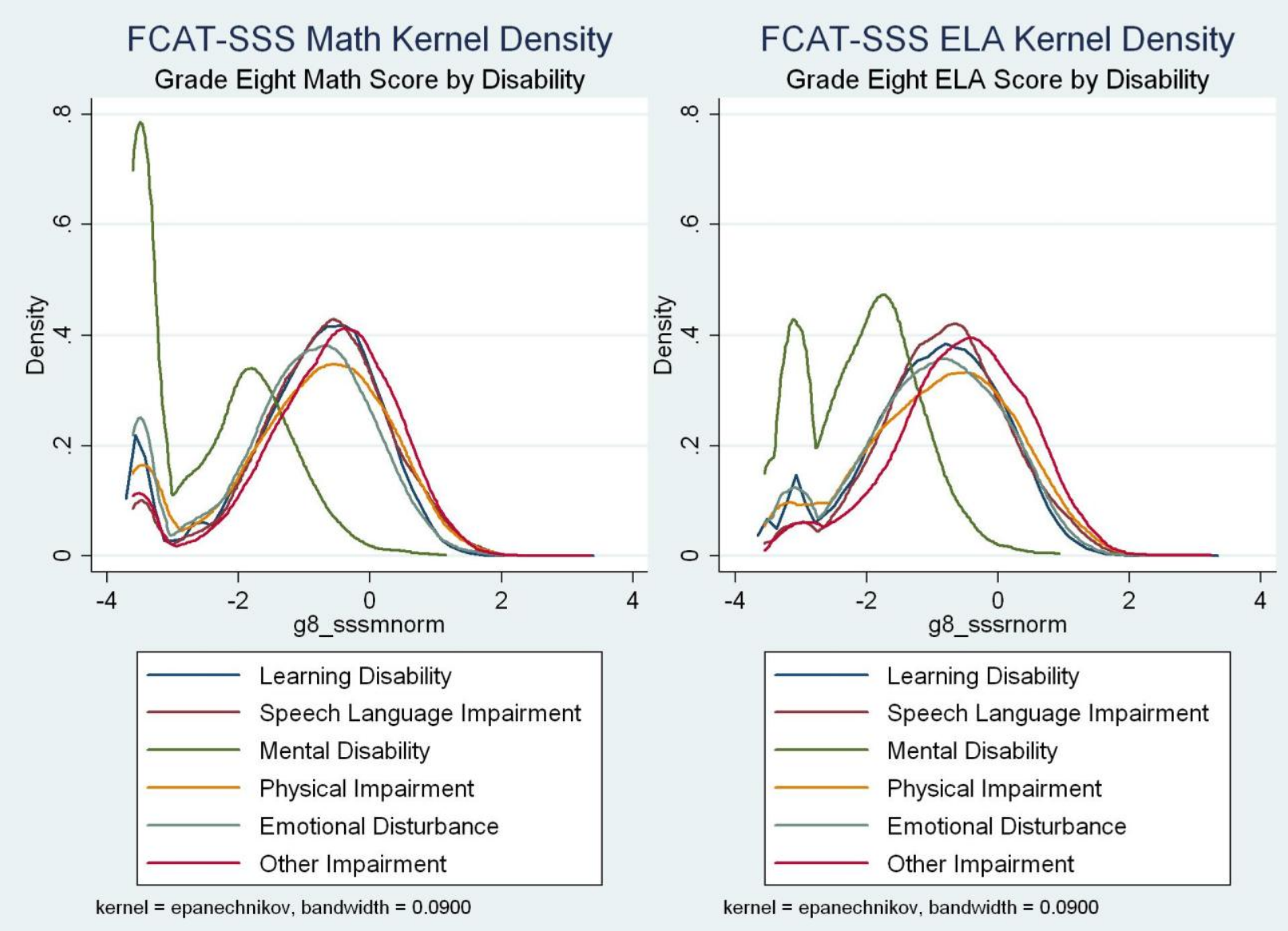


Table 2

Mean Outcomes in 2005/06 for Florida Public School Students with Disabilities who Entered Grade 9 in 1998/1999-2002/2003 by Disability Category

\begin{tabular}{|c|c|c|c|c|c|c|c|}
\hline & All & $\begin{array}{c}\text { Specific } \\
\text { Learning } \\
\text { Disability }\end{array}$ & $\begin{array}{l}\text { Speech- } \\
\text { Language } \\
\text { Disability }\end{array}$ & $\begin{array}{c}\text { Mental } \\
\text { Disability }\end{array}$ & $\begin{array}{l}\text { Physical } \\
\text { Disability }\end{array}$ & $\begin{array}{c}\text { Behavioral/ } \\
\text { Emotional } \\
\text { Disability }\end{array}$ & $\begin{array}{l}\text { Other } \\
\text { Disability }\end{array}$ \\
\hline Still attending & 0.414 & 0.381 & 0.379 & 0.430 & 0.323 & 0.544 & 0.472 \\
\hline Drop Out & 0.120 & 0.118 & 0.081 & 0.112 & 0.051 & 0.166 & 0.090 \\
\hline GED & 0.009 & 0.009 & 0.007 & 0.000 & 0.001 & 0.019 & 0.012 \\
\hline Certificate of Completion & 0.015 & 0.014 & 0.045 & 0.012 & 0.013 & 0.009 & 0.013 \\
\hline Special Diploma Option 2 & 0.018 & 0.021 & 0.008 & 0.018 & 0.007 & 0.016 & 0.013 \\
\hline Special Diploma Option 1 & 0.144 & 0.108 & 0.070 & 0.383 & 0.223 & 0.096 & 0.101 \\
\hline Alternative Standard Diploma & 0.059 & 0.074 & 0.073 & 0.018 & 0.094 & 0.028 & 0.048 \\
\hline Standard High School Diploma & 0.220 & 0.275 & 0.339 & 0.026 & 0.287 & 0.121 & 0.251 \\
\hline No. of Students & 130,114 & 79,791 & 6,094 & 17,378 & 3,392 & 20,318 & 3,141 \\
\hline
\end{tabular}

Note: The number of observations is slightly different from Table 1 due to the 2,111 student observations that have missing information on their whereabouts. 
Table 3

Descriptive Statistics for Special Education and Regular Education Teachers of Florida Public School Students with Disabilities who Entered Grade 9 in 1998/1999-2002/2003

\begin{tabular}{|c|c|c|c|c|}
\hline & \multicolumn{2}{|c|}{ Math Teachers } & \multicolumn{2}{|c|}{ English-Lang. Arts Teachers } \\
\hline & Special Ed. & Regular Ed. & Special Ed. & Regular Ed. \\
\hline Male & 0.281 & 0.381 & 0.174 & 0.199 \\
\hline Black & 0.198 & 0.172 & 0.181 & 0.152 \\
\hline Hispanic & 0.072 & 0.069 & 0.076 & 0.064 \\
\hline Asian & 0.007 & 0.008 & 0.004 & 0.003 \\
\hline Years of Experience & 8.189 & 9.092 & 8.267 & 9.385 \\
\hline Temporary Certification & 0.172 & 0.168 & 0.166 & 0.165 \\
\hline High School Math Certification & 0.116 & 0.328 & 0.002 & 0.004 \\
\hline Reading Certification & 0.015 & 0.011 & 0.044 & 0.056 \\
\hline Any Special Ed. Certification & 0.746 & 0.285 & 0.744 & 0.308 \\
\hline Ever NBPTS Certified & 0.041 & 0.048 & 0.050 & 0.055 \\
\hline Advanced Degree & 0.177 & 0.182 & 0.176 & 0.191 \\
\hline Current-Year Hours of Exceptional Ed. P.D. & 9.325 & 5.059 & 9.990 & 5.251 \\
\hline Exceptional Education Credits in College & 1.035 & 0.464 & 1.094 & 0.526 \\
\hline Total SAT-Equivalent Score & 946.4 & 997.5 & 955.8 & 990.6 \\
\hline Passed Gen. Knowledge Math Exam on $1^{\text {st }}$ Try & 0.516 & 0.733 & 0.443 & 0.524 \\
\hline Passed Gen. Knowledge Reading Exam on $1^{\text {st }}$ Try & ry $\quad 0.715$ & 0.788 & 0.761 & 0.843 \\
\hline
\end{tabular}

Note: "Special Ed. Teachers" are those teachers who taught one or more special education courses in the relevant subject area, independent of their certification status. Similarly, "Regular Ed. Teachers" are those who did not teach any special education courses, regardless of their certification. Reported statistics are student-weighted averages. 
Table 4. Competing Risk Analysis Results of the impact of teacher qualifications on Various Outcomes of Special Education Students Who have had at least one special education teacher

\begin{tabular}{|c|c|c|c|c|c|}
\hline & Dropout & $\begin{array}{l}\text { Special } \\
\text { Diploma } \\
\text { Option } 2\end{array}$ & $\begin{array}{l}\text { Special } \\
\text { Diploma } \\
\text { Option } 1\end{array}$ & $\begin{array}{l}\text { Alternative } \\
\text { Standard High } \\
\text { School } \\
\text { Diploma }\end{array}$ & $\begin{array}{l}\text { Standard High } \\
\text { School } \\
\text { Diploma }\end{array}$ \\
\hline \multirow[t]{2}{*}{ Female } & $0.948 \#$ & 0.729* & $1.137 * * *$ & $1.749 * * *$ & $1.054 *$ \\
\hline & $(-1.70)$ & $(-2.77)$ & (7.28) & (7.84) & (2.09) \\
\hline \multirow[t]{2}{*}{ Black } & $1.083^{*}$ & $0.719 *$ & 0.989 & $1.353^{*}$ & $0.873 * *$ \\
\hline & $(2.30)$ & $(-2.73)$ & $(-0.55)$ & (3.17) & $(-3.49)$ \\
\hline \multirow[t]{2}{*}{ Hispanic } & $1.273 * * *$ & $0.598 *$ & $0.889 * * *$ & $1.402 *$ & 0.950 \\
\hline & (5.53) & $(-2.89)$ & $(-4.05)$ & (3.18) & $(-1.31)$ \\
\hline \multirow[t]{2}{*}{ Asian } & 0.736 & 0.690 & 1.089 & 0.398 & 1.092 \\
\hline & $(-1.33)$ & $(-0.52)$ & $(0.89)$ & $(-1.36)$ & $(0.94)$ \\
\hline \multirow{2}{*}{$\begin{array}{l}\text { Limited English } \\
\text { Proficiency Grade } 9\end{array}$} & 0.857 & 1.080 & $1.170^{*}$ & 0.983 & 0.863 \\
\hline & $(-1.61)$ & $(0.21)$ & (2.96) & $(-0.06)$ & $(-1.19)$ \\
\hline \multirow{2}{*}{$\begin{array}{l}\text { Free/Reduced-Price } \\
\text { Lunch Grade } 8\end{array}$} & $1.591 * * *$ & 0.937 & $0.941 *$ & 1.060 & $0.779 * * *$ \\
\hline & (11.85) & $(-0.56)$ & $(-2.97)$ & $(0.70)$ & $(-8.49)$ \\
\hline \multirow{2}{*}{$\begin{array}{l}8^{\text {th }} \text { Grade Math Exam } \\
\text { Score }\end{array}$} & $0.998 * * *$ & $0.998 \#$ & $0.998 * * *$ & $0.995 * * *$ & $1.006 * * *$ \\
\hline & $(-6.19)$ & $(-1.68)$ & $(-8.93)$ & $(-8.86)$ & (19.76) \\
\hline \multirow{2}{*}{$\begin{array}{l}\text { Did not Take } 8^{\text {th }} \\
\text { Grade Math Exam }\end{array}$} & $0.792 * *$ & $0.599 *$ & $0.587 * * *$ & $0.179 * * *$ & $3.960 * * *$ \\
\hline & $(-3.68)$ & $(-2.33)$ & $(-14.39)$ & $(-8.72)$ & (14.25) \\
\hline \multirow{2}{*}{$\begin{array}{l}\text { Specific Learning } \\
\text { Disability Grade } 9\end{array}$} & $1.471 *$ & 0.904 & $0.800 * *$ & 1.199 & 1.033 \\
\hline & (2.75) & $(-0.33)$ & $(-3.59)$ & $(0.67)$ & $(0.40)$ \\
\hline \multirow{2}{*}{$\begin{array}{l}\text { Speech-Language } \\
\text { Disability Grade } 9\end{array}$} & 1.046 & 0.512 & 0.934 & 0.877 & 0.997 \\
\hline & $(0.26)$ & $(-1.44)$ & $(-0.83)$ & $(-0.43)$ & $(-0.04)$ \\
\hline \multirow{2}{*}{$\begin{array}{l}\text { Mental Disability } \\
\text { Grade } 9\end{array}$} & 0.864 & $0.485^{*}$ & $0.846^{*}$ & 0.953 & 0.931 \\
\hline & $(-1.03)$ & $(-2.22)$ & $(-2.67)$ & $(-0.14)$ & $(-0.63)$ \\
\hline \multirow{2}{*}{$\begin{array}{l}\text { Physical Disability } \\
\text { Grade } 9\end{array}$} & $0.578^{*}$ & $0.248 *$ & 0.954 & 1.371 & 1.167 \\
\hline & $(-2.94)$ & $(-2.38)$ & $(-0.65)$ & $(0.96)$ & (1.61) \\
\hline $\begin{array}{l}\text { Behavioral/Emotional } \\
\text { Disability Grade } 9\end{array}$ & $1.968 * * *$ & $0.496^{*}$ & $0.589 * * *$ & 0.934 & 0.866 \\
\hline
\end{tabular}




\begin{tabular}{|c|c|c|c|c|c|}
\hline & $(4.77)$ & $(-2.08)$ & $(-7.82)$ & $(-0.23)$ & $(-1.55)$ \\
\hline \multirow{2}{*}{$\begin{array}{l}<40 \% \text { of Time } \\
\text { w/Non-disabled-G. } 9\end{array}$} & 0.983 & $0.806 \#$ & $0.962 \#$ & 1.019 & $0.911 \#$ \\
\hline & $(-0.49)$ & $(-1.68)$ & $(-1.89)$ & $(0.17)$ & $(-1.91)$ \\
\hline \multirow{2}{*}{$\begin{array}{l}\text { S. E. Math Teacher - } \\
0-2 \text { Yrs. Exp. }\end{array}$} & $1.175^{* * *}$ & 0.973 & $1.050 *$ & 1.031 & $0.909 *$ \\
\hline & (4.63) & $(-0.21)$ & $(2.20)$ & $(0.35)$ & $(-2.87)$ \\
\hline \multirow{2}{*}{$\begin{array}{l}\text { S. E. Math Teacher - } \\
\text { 3-9 Yrs. Exp. }\end{array}$} & 0.944 & 1.066 & $1.085^{* *}$ & 1.069 & 0.979 \\
\hline & $(-1.60)$ & $(0.52)$ & $(3.86)$ & $(0.78)$ & $(-0.78)$ \\
\hline \multirow{2}{*}{$\begin{array}{l}\text { S. E. Math Teacher - } \\
\text { Adv. Degree }\end{array}$} & $0.943 \#$ & 0.973 & $0.967 \#$ & 0.981 & $1.043 \#$ \\
\hline & $(-1.94)$ & $(-0.25)$ & $(-1.82)$ & $(-0.26)$ & $(1.78)$ \\
\hline \multirow{2}{*}{$\begin{array}{l}\text { S. E. Math Teacher - } \\
\text { Sp. Ed. Cert. }\end{array}$} & $1.249 * * *$ & $1.778^{*}$ & $1.685^{* * *}$ & $0.311 * * *$ & $0.513 * * *$ \\
\hline & $(4.84)$ & $(2.58)$ & (12.78) & $(-9.19)$ & $(-10.74)$ \\
\hline \multirow{2}{*}{$\begin{array}{l}\text { S. E. Math Teacher - } \\
\text { High School Math } \\
\text { Cert. }\end{array}$} & $0.668 * * *$ & $0.331 * *$ & $0.157 * * *$ & 1.037 & $2.832 * * *$ \\
\hline & $(-5.72)$ & $(-3.59)$ & $(-20.13)$ & $(0.35)$ & (17.66) \\
\hline $\begin{array}{l}\text { Student Year } \\
\text { Observations }\end{array}$ & 116900 & 120863 & 120236 & 120866 & 120674 \\
\hline Student Observations & 58300 & 59713 & 59692 & 59712 & 59683 \\
\hline $\begin{array}{l}\text { Student Observations } \\
\text { that Failed }\end{array}$ & 4766 & 389 & 8504 & 716 & 3601 \\
\hline $\begin{array}{l}\text { Student Observations } \\
\text { that Failed Due to } \\
\text { Other Events }\end{array}$ & 12965 & 17405 & 9440 & 17077 & 14203 \\
\hline $\begin{array}{l}\text { Censored Student } \\
\text { Observations }\end{array}$ & 40569 & 41919 & 41748 & 41919 & 41879 \\
\hline AIC & 95359.14 & 7644.682 & 162719.9 & 12597.31 & 65064.03 \\
\hline
\end{tabular}

Note: Cohort dummies and minutes spent in special education or general education math and ELA classes were included in all models. 
Table 5. Competing Risk Analysis Results of the impact of teacher qualifications on Special Education Students Who have had at least one general education teacher

\begin{tabular}{|c|c|c|c|c|c|}
\hline & Dropout & $\begin{array}{l}\text { Special } \\
\text { Diploma } \\
\text { Option } 2\end{array}$ & $\begin{array}{l}\text { Special } \\
\text { Diploma } \\
\text { Option } 1\end{array}$ & $\begin{array}{l}\text { Alternative Standard } \\
\text { High School Diploma }\end{array}$ & $\begin{array}{l}\text { Standard High } \\
\text { School Diploma }\end{array}$ \\
\hline \multirow[t]{2}{*}{ Female } & 0.983 & 0.892 & $1.211^{* * *}$ & $1.526 * * *$ & $1.057 * * *$ \\
\hline & $(-0.58)$ & $(-0.60)$ & (3.36) & (12.29) & (4.17) \\
\hline \multirow[t]{2}{*}{ Black } & 0.972 & 0.919 & 0.965 & $1.447 * * *$ & $0.864 * * *$ \\
\hline & $(-0.81)$ & $(-0.40)$ & $(-0.52)$ & (7.70) & $(-6.87)$ \\
\hline \multirow[t]{2}{*}{ Hispanic } & $1.380 * * *$ & $0.474 *$ & $0.684 * * *$ & $1.427 * * *$ & 1.001 \\
\hline & $(8.63)$ & $(-2.44)$ & $(-4.06)$ & (7.16) & $(0.05)$ \\
\hline \multirow[t]{2}{*}{ Asian } & 0.894 & $0.000 * * *$ & 0.737 & 0.945 & 1.071 \\
\hline & $(-0.59)$ & $(-80.26)$ & $(-0.71)$ & $(-0.26)$ & $(1.36)$ \\
\hline \multirow{2}{*}{$\begin{array}{l}\text { Limited English } \\
\text { Proficiency Grade } 9\end{array}$} & $0.650^{* *}$ & $5.549 * * *$ & 1.173 & $1.316^{*}$ & $0.851^{*}$ \\
\hline & $(-3.74)$ & $(4.30)$ & $(0.70)$ & (2.36) & $(-2.03)$ \\
\hline \multirow{2}{*}{$\begin{array}{l}\text { Free/Reduced-Price } \\
\text { Lunch Grade } 8\end{array}$} & $1.652 * * *$ & 1.372 & $1.251^{*}$ & 1.012 & $0.793 * * *$ \\
\hline & $(15.00)$ & (1.46) & $(3.22)$ & $(0.29)$ & $(-14.99)$ \\
\hline \multirow{2}{*}{$\begin{array}{l}8^{\text {th }} \text { Grade Math Exam } \\
\text { Score }\end{array}$} & $0.996^{* * *}$ & 0.998 & $0.993 * * *$ & $0.994 * * *$ & $1.006 * * *$ \\
\hline & $(-17.25)$ & $(-1.38)$ & $(-14.12)$ & $(-22.50)$ & (35.73) \\
\hline \multirow{2}{*}{$\begin{array}{l}\text { Did not Take } 8^{\text {th }} \text { Grade } \\
\text { Math Exam }\end{array}$} & $0.624 * * *$ & 1.052 & $0.260 * * *$ & $0.206^{* * *}$ & $3.881 * * *$ \\
\hline & $(-7.45)$ & $(0.12)$ & $(-12.03)$ & $(-17.61)$ & $(24.80)$ \\
\hline \multirow{2}{*}{$\begin{array}{l}\text { Specific Learning } \\
\text { Disability Grade } 9\end{array}$} & 1.170 & 1543851.531 & 1.200 & $1.258 \#$ & 1.006 \\
\hline & $(1.42)$ & (.) & $(0.77)$ & (1.68) & $(0.13)$ \\
\hline \multirow[t]{2}{*}{$\begin{array}{l}\text { Speech-Language } \\
\text { Disability Grade } 9\end{array}$} & 1.016 & $\begin{array}{c}878633.107 * \\
* *\end{array}$ & 1.143 & 1.015 & 0.972 \\
\hline & $(0.12)$ & (34.04) & $(0.49)$ & $(0.10)$ & $(-0.59)$ \\
\hline \multirow[t]{2}{*}{$\begin{array}{l}\text { Mental Disability Grade } \\
9\end{array}$} & $0.734 *$ & $\begin{array}{c}1131815.155 \\
* * *\end{array}$ & $1.913 *$ & 1.298 & $0.686^{* *}$ \\
\hline & $(-2.22)$ & $(38.87)$ & $(2.62)$ & (1.61) & $(-3.63)$ \\
\hline \multirow[t]{2}{*}{$\begin{array}{l}\text { Physical Disability } \\
\text { Grade } 9\end{array}$} & $0.524 * *$ & $\begin{array}{c}409832.027 * \\
* *\end{array}$ & $1.753^{*}$ & $1.605^{*}$ & $1.155^{*}$ \\
\hline & $(-3.83)$ & (13.12) & $(2.02)$ & (2.97) & $(2.71)$ \\
\hline \multirow[t]{2}{*}{$\begin{array}{l}\text { Behavioral/Emotional } \\
\text { Disability Grade } 9\end{array}$} & $1.552 * *$ & $\begin{array}{c}1054396.392 \\
* * *\end{array}$ & 0.735 & $0.715^{*}$ & $0.800 * * *$ \\
\hline & $(3.87)$ & (104.47) & $(-1.23)$ & $(-2.23)$ & $(-4.39)$ \\
\hline$<40 \%$ of Time w/Non- & $1.171 * * *$ & 1.189 & $1.350 * * *$ & 0.975 & $0.884 * * *$ \\
\hline
\end{tabular}




\begin{tabular}{|c|c|c|c|c|c|}
\hline \multicolumn{6}{|l|}{ disabled-G. 9} \\
\hline & $(4.61)$ & $(0.69)$ & $(4.31)$ & $(-0.51)$ & $(-4.60)$ \\
\hline \multirow{2}{*}{$\begin{array}{l}\text { R. E. Math Teacher - 0-2 } \\
\text { Yrs. Exp. }\end{array}$} & $1.242 * * *$ & 0.855 & 1.053 & $1.090 *$ & $0.963^{*}$ \\
\hline & $(6.66)$ & $(-0.73)$ & $(0.76)$ & $(2.01)$ & $(-2.23)$ \\
\hline \multirow{2}{*}{$\begin{array}{l}\text { R. E. Math Teacher - 3-9 } \\
\text { Yrs. Exp. }\end{array}$} & 0.963 & 0.832 & 0.933 & 1.028 & $0.969^{*}$ \\
\hline & $(-1.09)$ & $(-0.89)$ & $(-1.00)$ & $(0.65)$ & $(-2.15)$ \\
\hline \multirow{2}{*}{$\begin{array}{l}\text { R. E. Math Teacher - } \\
\text { Adv. Degree }\end{array}$} & 0.978 & 1.090 & $0.908 \#$ & 0.995 & $1.030 *$ \\
\hline & $(-0.79)$ & $(0.49)$ & $(-1.69)$ & $(-0.14)$ & $(2.25)$ \\
\hline \multirow{2}{*}{$\begin{array}{l}\text { R. E. Math Teacher - Sp. } \\
\text { Ed. Cert. }\end{array}$} & $1.309 * * *$ & 1.195 & $1.404 * * *$ & 1.063 & $0.926^{*}$ \\
\hline & (7.79) & $(0.75)$ & $(4.70)$ & $(1.22)$ & $(-2.66)$ \\
\hline \multirow{2}{*}{$\begin{array}{l}\text { R. E. Math Teacher - } \\
\text { High School Math Cert. }\end{array}$} & $0.745^{* * *}$ & 0.697 & $0.810 *$ & 0.972 & $1.689 * * *$ \\
\hline & $(-7.68)$ & $(-1.56)$ & $(-2.71)$ & $(-0.62)$ & (21.54) \\
\hline $\begin{array}{l}\text { Student Year } \\
\text { Observations }\end{array}$ & 161773 & 166016 & 165968 & 166018 & 165824 \\
\hline Student Observations & 78475 & 79979 & 79964 & 79980 & 79949 \\
\hline $\begin{array}{l}\text { Student Observations } \\
\text { that Failed }\end{array}$ & 5384 & 137 & 1215 & 2884 & 11287 \\
\hline $\begin{array}{l}\text { Student Observations } \\
\text { that Failed Due to Other } \\
\text { Events }\end{array}$ & 16132 & 21299 & 20211 & 18552 & 10174 \\
\hline $\begin{array}{l}\text { Censored Student } \\
\text { Observations }\end{array}$ & 56959 & 58543 & 58538 & 58544 & 58488 \\
\hline AIC & 110550 & 2788.936 & 22823.53 & 55842.1 & 223269.5 \\
\hline
\end{tabular}


Table 6. Competing Risk Analysis Results of the impact of teacher qualifications on Special Education Students Who have had at least one general education teacher and one special education teacher

\begin{tabular}{|c|c|c|c|c|}
\hline & Dropout & $\begin{array}{l}\text { Special Diploma } \\
\text { Option } 1\end{array}$ & $\begin{array}{l}\text { Alternative } \\
\text { Standard High } \\
\text { School } \\
\text { Diploma }\end{array}$ & $\begin{array}{l}\text { Standard High } \\
\text { School } \\
\text { Diploma }\end{array}$ \\
\hline \multirow[t]{2}{*}{ Female } & 0.946 & 1.145 & $1.699 * * *$ & 1.027 \\
\hline & $(-0.81)$ & (1.26) & (7.40) & (1.11) \\
\hline \multirow[t]{2}{*}{ Black } & 1.094 & 0.991 & $1.295^{*}$ & $0.902^{*}$ \\
\hline & (1.15) & $(-0.07)$ & $(2.62)$ & $(-2.58)$ \\
\hline \multirow[t]{2}{*}{ Hispanic } & $1.334 *$ & 0.884 & $1.328^{*}$ & 0.974 \\
\hline & (3.18) & $(-0.76)$ & $(2.65)$ & $(-0.69)$ \\
\hline \multirow[t]{2}{*}{ Asian } & 1.099 & 1.926 & 0.419 & 1.046 \\
\hline & $(0.27)$ & (1.48) & $(-1.31)$ & $(0.51)$ \\
\hline \multirow{2}{*}{$\begin{array}{l}\text { Limited English } \\
\text { Proficiency Grade } 9\end{array}$} & 0.873 & 1.061 & 1.270 & 0.960 \\
\hline & $(-0.58)$ & $(0.16)$ & $(0.92)$ & $(-0.33)$ \\
\hline \multirow{2}{*}{$\begin{array}{l}\text { Free/Reduced-Price } \\
\text { Lunch Grade } 8\end{array}$} & $1.462 * * *$ & 1.221 & 1.081 & $0.824 * * *$ \\
\hline & $(4.88)$ & (1.58) & $(0.93)$ & $(-6.80)$ \\
\hline \multirow{2}{*}{$\begin{array}{l}8^{\text {th }} \text { Grade Math Exam } \\
\text { Score }\end{array}$} & $0.996^{* * *}$ & $0.994 * * *$ & $0.994 * * *$ & $1.006 * * *$ \\
\hline & $(-7.20)$ & $(-7.08)$ & $(-11.75)$ & (18.45) \\
\hline \multirow{2}{*}{$\begin{array}{l}\text { Did not Take } 8^{\text {th }} \\
\text { Grade Math Exam }\end{array}$} & $0.635^{* *}$ & $0.269 * * *$ & $0.149 * * *$ & $4.292 * * *$ \\
\hline & $(-3.32)$ & $(-6.40)$ & $(-9.22)$ & (13.87) \\
\hline \multirow{2}{*}{$\begin{array}{l}\text { Specific Learning } \\
\text { Disability Grade } 9\end{array}$} & 1.268 & 0.813 & 1.153 & 1.090 \\
\hline & (0.97) & $(-0.56)$ & $(0.52)$ & (1.08) \\
\hline \multirow{2}{*}{$\begin{array}{l}\text { Speech-Language } \\
\text { Disability Grade } 9\end{array}$} & 1.195 & 0.899 & 0.860 & 1.040 \\
\hline & $(0.65)$ & $(-0.24)$ & $(-0.50)$ & $(0.45)$ \\
\hline \multirow{2}{*}{$\begin{array}{l}\text { Mental Disability } \\
\text { Grade } 9\end{array}$} & 0.809 & 1.209 & 1.395 & 0.950 \\
\hline & $(-0.73)$ & $(0.47)$ & (1.02) & $(-0.28)$ \\
\hline \multirow{2}{*}{$\begin{array}{l}\text { Physical Disability } \\
\text { Grade } 9\end{array}$} & $0.272 *$ & 1.215 & 1.351 & $1.237 *$ \\
\hline & $(-2.77)$ & $(0.43)$ & $(0.91)$ & (2.29) \\
\hline $\begin{array}{l}\text { Behavioral/Emotional } \\
\text { Disability Grade } 9\end{array}$ & $1.530 \#$ & $0.518 \#$ & 0.758 & 0.892 \\
\hline
\end{tabular}




\begin{tabular}{|c|c|c|c|c|}
\hline & $(1.69)$ & $(-1.66)$ & $(-0.93)$ & $(-1.25)$ \\
\hline \multirow{2}{*}{$\begin{array}{l}<40 \% \text { of Time } \\
\text { w/Non-disabled }- \text { G. } \\
9\end{array}$} & 1.129 & $1.267 \#$ & 1.023 & 0.965 \\
\hline & $(1.52)$ & $(1.80)$ & $(0.20)$ & $(-0.70)$ \\
\hline \multirow{2}{*}{$\begin{array}{l}\text { S. E. Math Teacher - } \\
0-2 \text { Yrs. Exp. }\end{array}$} & 1.107 & 0.788 & 0.803 & 0.871 \\
\hline & $(0.78)$ & $(-1.45)$ & $(-1.10)$ & $(-0.50)$ \\
\hline \multirow{2}{*}{$\begin{array}{l}\text { S. E. Math Teacher - } \\
\text { 3-9 Yrs. Exp. }\end{array}$} & 1.022 & 0.867 & 1.047 & 0.903 \\
\hline & $(0.17)$ & $(-0.70)$ & $(0.23)$ & $(-0.58)$ \\
\hline \multirow{2}{*}{$\begin{array}{l}\text { S. E. Math Teacher - } \\
\text { Adv. Degree }\end{array}$} & 1.111 & 0.846 & $1.569 *$ & 1.180 \\
\hline & $(1.12)$ & $(-1.02)$ & (2.19) & $(0.98)$ \\
\hline \multirow{2}{*}{$\begin{array}{l}\text { S. E. Math Teacher - } \\
\text { Sp. Ed. Cert. }\end{array}$} & 1.059 & $1.979 *$ & $0.338 * * *$ & $0.427 * * *$ \\
\hline & $(0.47)$ & (3.07) & $(-5.05)$ & $(-4.21)$ \\
\hline \multirow{2}{*}{$\begin{array}{l}\text { S. E. Math Teacher - } \\
\text { High School Math } \\
\text { Cert. }\end{array}$} & $0.678^{*}$ & $0.380 * *$ & $5.300 * * *$ & $2.314^{*}$ \\
\hline & $(-2.16)$ & $(-3.50)$ & $(4.70)$ & $(2.43)$ \\
\hline \multirow{2}{*}{$\begin{array}{l}\text { R. E. Math Teacher - } \\
\text { 0-2 Yrs. Exp. }\end{array}$} & 1.160 & 1.253 & 1.360 & 1.098 \\
\hline & $(1.15)$ & $(1.42)$ & $(1.55)$ & $(0.34)$ \\
\hline \multirow{2}{*}{$\begin{array}{l}\text { R. E. Math Teacher - } \\
\text { 3-9 Yrs. Exp. }\end{array}$} & 1.050 & 0.988 & 1.026 & 1.063 \\
\hline & $(0.38)$ & $(-0.06)$ & $(0.13)$ & $(0.35)$ \\
\hline \multirow{2}{*}{$\begin{array}{l}\text { R. E. Math Teacher - } \\
\text { Adv. Degree }\end{array}$} & $0.854 \#$ & 1.005 & $0.622^{*}$ & 0.866 \\
\hline & $(-1.67)$ & $(0.03)$ & $(-2.30)$ & $(-0.85)$ \\
\hline \multirow{2}{*}{$\begin{array}{l}\text { R. E. Math Teacher - } \\
\text { Sp. Ed. Cert. }\end{array}$} & $1.335^{*}$ & 0.921 & $2.815 * * *$ & $1.996 * *$ \\
\hline & $(2.46)$ & $(-0.40)$ & (4.74) & $(3.36)$ \\
\hline \multirow{2}{*}{$\begin{array}{l}\text { R. E. Math Teacher - } \\
\text { High School Math } \\
\text { Cert. }\end{array}$} & 1.008 & $1.550 \#$ & $0.171 * * *$ & 0.861 \\
\hline & $(0.05)$ & $(1.90)$ & $(-4.93)$ & $(-0.43)$ \\
\hline $\begin{array}{l}\text { Student Year } \\
\text { Observations }\end{array}$ & 30255 & 31158 & 31173 & 31140 \\
\hline Student Observations & 22863 & 23531 & 23542 & 23523 \\
\hline $\begin{array}{l}\text { Student Observations } \\
\text { that Failed }\end{array}$ & 1039 & 369 & 692 & 3181 \\
\hline
\end{tabular}




\begin{tabular}{l|rccc}
\hline $\begin{array}{l}\text { Student Observations } \\
\text { that Failed Due to } \\
\text { Other Events }\end{array}$ & 4419 & 5269 & 4954 & 2454 \\
$\begin{array}{l}\text { Censored Student } \\
\text { Observations }\end{array}$ & 17405 & 17893 & 17896 & 17888 \\
AIC & 17904.7 & 5886.826 & 11558.96 & 54198.78 \\
\hline
\end{tabular}

Note: The outcome of obtaining special diploma option 2 encountered convergence problems in this iteration and therefore results are omitted in this table. 
Table 7. Competing Risk Analysis Results of the impact of exposure to High quality teachers on Special Education Students

\begin{tabular}{l|lllll}
\hline & Dropout & $\begin{array}{l}\text { Special Diploma } \\
\text { Option 2 }\end{array}$ & $\begin{array}{l}\text { Special Diploma } \\
\text { Option 1 }\end{array}$ & $\begin{array}{l}\text { Alternative } \\
\text { Standard High } \\
\text { School Diploma }\end{array}$ & $\begin{array}{l}\text { Standard High } \\
\text { School } \\
\text { Diploma }\end{array}$ \\
\hline $\begin{array}{l}\text { High quality teachers } \\
\text { in special education } \\
\text { classroom }\end{array}$ & $0.951^{*}$ & $1.325^{* * *}$ & $1.233^{* * *}$ & $0.416^{* * * *}$ & $0.603^{* * * *}$ \\
& $(-2.37)$ & -4.85 & & & \\
$\begin{array}{l}\text { High quality teachers } \\
\begin{array}{l}\text { in general education } \\
\text { classroom }\end{array}\end{array}$ & $0.596^{* * *}$ & $0.431^{* * *}$ & -14.45 & $(-12.54)$ & $(-14.61)$ \\
& & & $0.417^{* * *}$ & $0.946 *$ & $1.285^{* * *}$ \\
& $(-19.41)$ & $(-9.22)$ & $(-20.79)$ & $(-1.96)$ & -26.98 \\
$\begin{array}{l}\text { high quality teachers } \\
\text { in either classrooms }\end{array}$ & $0.762 * * *$ & $0.890^{*}$ & 1.012 & $0.789^{* * *}$ & $1.170^{* * *}$ \\
& $(-16.06)$ & $(-2.49)$ & -0.92 & $(-8.92)$ & -17.36 \\
\hline
\end{tabular}

Note: A high quality special education teacher in special education classroom is defined as someone with advanced degree, special education certification, and more than five years of experience. A high quality general education teachers in general education classroom is defined as someone with advanced degree, high school math certification, and more than five years of experience. 


\begin{tabular}{|c|c|c|c|c|c|}
\hline Outcome & $\begin{array}{l}\text { Classroom } \\
\text { and Treatment }\end{array}$ & Estimator & Treatment & Control & Difference \\
\hline dropping out & $\begin{array}{l}\text { High quality } \\
\text { teachers in special } \\
\text { ed classroom } \\
\mathrm{N} \text { treated }=15471 \%\end{array}$ & ATT & 0.1349 & 0.1176 & $\begin{array}{l}0.0173 * * * \\
{[0.0028]} \\
-0.0092 * * \\
{[0.0053]}\end{array}$ \\
\hline dropping out & $\begin{array}{l}\text { High quality } \\
\text { teachers in general } \\
\text { ed classroom } \\
\mathrm{N} \text { treated=17717 }\end{array}$ & ATT & 0.0658 & 0.0946 & $\begin{array}{l}-0.0639 * * * \\
{[0.0026]} \\
-0.0288 * * * \\
{[0.0039]}\end{array}$ \\
\hline dropping out & $\begin{array}{l}\text { high quality teachers } \\
\text { in either classrooms } \\
\mathrm{N} \text { treated }=32651 \ddagger\end{array}$ & $\begin{array}{l}\text { OLS } \\
\text { ATT }\end{array}$ & $\begin{array}{l}0.0974 \\
0.0974\end{array}$ & $\begin{array}{l}0.1286 \\
0.1205\end{array}$ & $\begin{array}{l}-0.0311 * * * \\
{[0.0021]} \\
-0.0231 * * * \\
{[0.0033]}\end{array}$ \\
\hline GED & $\begin{array}{l}\text { High quality } \\
\text { teachers in special } \\
\text { ed classroom } \\
\mathrm{N} \text { treated }=15471 \%\end{array}$ & ATT & 0.0043 & 0.0047 & $\begin{array}{l}-0.0059 * * * \\
{[0.0008]} \\
-0.0004 \\
{[0.0011]}\end{array}$ \\
\hline GED & $\begin{array}{l}\text { High quality } \\
\text { teachers in general } \\
\text { ed classroom } \\
\mathrm{N} \text { treated=17717 }\end{array}$ & ATT & 0.0112 & 0.0133 & $\begin{array}{l}0.0021 * * * \\
{[0.0008]} \\
-0.0021 \\
{[0.0015]}\end{array}$ \\
\hline GED & $\begin{array}{l}\text { high quality teachers } \\
\text { in either classrooms } \\
\mathrm{N} \text { treated=32651 }\end{array}$ & OLS & 0.0078 & 0.0105 & $\begin{array}{l}-0.0022 * * * \\
{[0.0006]} \\
-0.0026 * * \\
{[0.0010]}\end{array}$ \\
\hline $\begin{array}{l}\text { certificate of } \\
\text { completion }\end{array}$ & $\begin{array}{l}\text { High quality } \\
\text { teachers in special } \\
\text { ed classroom } \\
\mathrm{N} \text { treated=15471 } \\
\text { High quality } \\
\text { teachers in general } \\
\text { ed classroom } \\
\mathrm{N} \text { treated=17717 }\end{array}$ & $\begin{array}{l}\text { OLS } \\
\text { ATT }\end{array}$ & 0.0075 & $\begin{array}{l}0.0163 \\
0.0117\end{array}$ & $\begin{array}{l}-0.0088 * * * \\
{[0.0011]} \\
-0.0042 * * * \\
{[0.0016]}\end{array}$ \\
\hline
\end{tabular}




\begin{tabular}{|c|c|c|c|c|c|}
\hline \multirow[t]{2}{*}{$\begin{array}{l}\text { certificate of } \\
\text { completion }\end{array}$} & $\begin{array}{l}\text { high quality teachers } \\
\text { in either classrooms }\end{array}$ & OLS & 0.0155 & 0.0150 & $\begin{array}{l}0.0005 \\
{[0.0008]}\end{array}$ \\
\hline & $\mathrm{N}$ treated $=32651 \ddagger$ & ATT & 0.0155 & 0.0151 & $\begin{array}{l}0.0003 \\
{[0.0013]}\end{array}$ \\
\hline \multirow[t]{2}{*}{$\begin{array}{l}\text { special } \\
\text { diploma } \\
\text { option } 2\end{array}$} & $\begin{array}{l}\text { High quality } \\
\text { teachers in special } \\
\text { ed classroom }\end{array}$ & OLS & 0.0316 & 0.0168 & $\begin{array}{l}0.0148 * * * \\
{[0.0012]}\end{array}$ \\
\hline & $\mathrm{N}$ treated $=15471 \ddagger$ & ATT & 0.0316 & 0.0236 & $\begin{array}{l}0.0080 * * * \\
{[0.0024]}\end{array}$ \\
\hline \multirow[t]{2}{*}{$\begin{array}{l}\text { special } \\
\text { diploma } \\
\text { option } 2\end{array}$} & $\begin{array}{l}\text { High quality } \\
\text { teachers in general } \\
\text { ed classroom }\end{array}$ & OLS & 0.0076 & 0.0207 & $\begin{array}{l}-0.0131 * * * \\
{[0.0011]}\end{array}$ \\
\hline & $\mathrm{N}$ treated $=17717$ & ATT & 0.0076 & 0.0115 & $\begin{array}{l}-0.0039 * * * \\
{[0.0015]}\end{array}$ \\
\hline \multirow[t]{2}{*}{$\begin{array}{l}\text { special } \\
\text { diploma } \\
\text { option } 2\end{array}$} & $\begin{array}{l}\text { high quality teachers } \\
\text { in either classrooms }\end{array}$ & OLS & 0.0187 & 0.0187 & $\begin{array}{l}0.0000 \\
{[0.0009]}\end{array}$ \\
\hline & $\mathrm{N}$ treated $=32651 \dagger$ & ATT & 0.0187 & 0.0176 & $\begin{array}{l}0.011 \\
{[0.0014]}\end{array}$ \\
\hline \multirow[t]{2}{*}{$\begin{array}{l}\text { special } \\
\text { diploma } \\
\text { option } 1\end{array}$} & $\begin{array}{l}\text { High quality } \\
\text { teachers in special } \\
\text { ed classroom }\end{array}$ & OLS & 0.3557 & 0.1149 & $\begin{array}{l}0.2408 * * * \\
{[0.0030]}\end{array}$ \\
\hline & $\mathrm{N}$ treated $=15471 \ddagger$ & ATT & 0.3557 & 0.2882 & $\begin{array}{l}0.0676 * * * \\
{[0.0068]}\end{array}$ \\
\hline \multirow[t]{2}{*}{$\begin{array}{l}\text { special } \\
\text { diploma } \\
\text { option } 1\end{array}$} & $\begin{array}{l}\text { High quality } \\
\text { teachers in general } \\
\text { ed classroom }\end{array}$ & OLS & 0.0321 & 0.1669 & $\begin{array}{l}-0.1348^{* * *} \\
{[0.0029]}\end{array}$ \\
\hline & $\mathrm{N}$ treated $=17717$ & ATT & 0.0321 & 0.0497 & $\begin{array}{l}-0.0176 * * * \\
{[0.0030]}\end{array}$ \\
\hline \multirow[t]{2}{*}{$\begin{array}{l}\text { special } \\
\text { diploma } \\
\text { option } 1\end{array}$} & $\begin{array}{l}\text { high quality teachers } \\
\text { in either classrooms }\end{array}$ & OLS & 0.1829 & 0.1326 & $\begin{array}{l}0.0503 * * * \\
{[0.0023]}\end{array}$ \\
\hline & $\mathrm{N}$ treated $=32651 \dagger$ & ATT & 0.1829 & 0.1618 & $\begin{array}{l}0.0211 * * * \\
{[0.0038]}\end{array}$ \\
\hline \multirow[t]{2}{*}{$\begin{array}{l}\text { alternative } \\
\text { diploma }\end{array}$} & $\begin{array}{l}\text { High quality } \\
\text { teachers in special } \\
\text { ed classroom } \\
\mathrm{N} \text { treated }=15471 \pm\end{array}$ & OLS & 0.0137 & 0.0698 & $\begin{array}{l}-0.0561 * * * \\
{[0.0021]}\end{array}$ \\
\hline & & ATT & 0.0137 & 0.0263 & $\begin{array}{l}-0.0126 * * * \\
{[0.0025]}\end{array}$ \\
\hline \multirow[t]{2}{*}{$\begin{array}{l}\text { alternative } \\
\text { diploma }\end{array}$} & $\begin{array}{l}\text { High quality } \\
\text { teachers in general } \\
\text { ed classroom }\end{array}$ & OLS & 0.0832 & 0.0588 & $\begin{array}{l}0.0244 * * * \\
{[0.0020]}\end{array}$ \\
\hline & & ATT & 0.0832 & 0.0688 & $0.0144 * * *$ \\
\hline
\end{tabular}




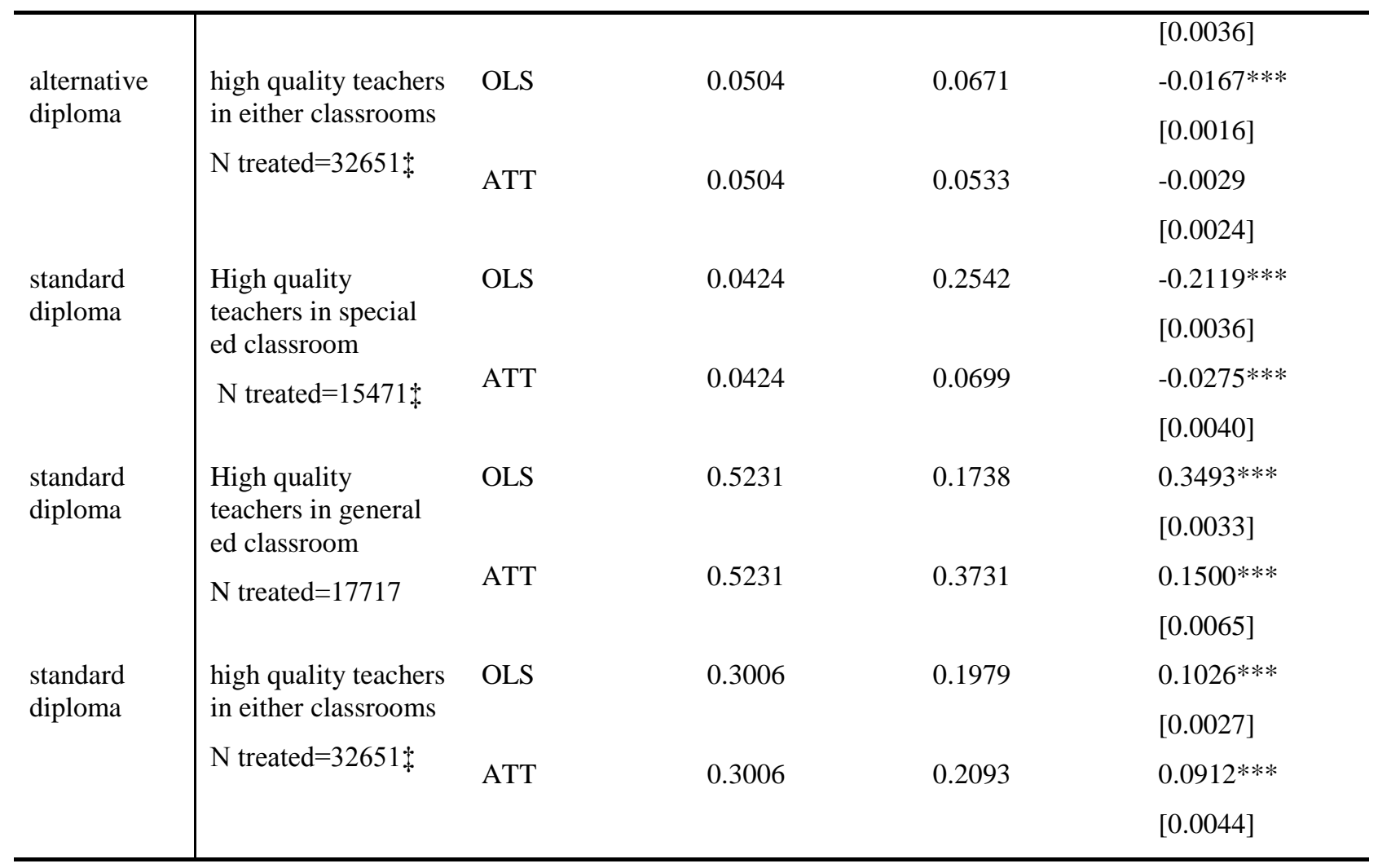

